\title{
Performance Evaluation of Industry-Education Integration in Higher Vocational Colleges: An Evidence from China
}

\author{
https://doi.org/10.3991/ijet.v15i23.19025 \\ Fei Gao $(\bowtie)$ \\ Zhejiang Shuren University, Hangzhou, China \\ gaofeibde163.com \\ Peng Zhang \\ Zhejiang University, Hangzhou, China
}

\begin{abstract}
The integration of industry and education promotes the cooperation between colleges and enterprises, and contributes to regional development. This paper aims to evaluate the performance of industry-education integration in higher vocational colleges of the Yangtze River Delta. Firstly, 138 higher vocational colleges were selected from the Yangtze River Delta as the research samples. Then, a comprehensive evaluation system was designed, including 11 evaluation indices. On this basis, the 2018 data of the samples were evaluated from the perspectives of faculty, teaching, scientific research, and service. The results show that, in the Yangtze River Delta, the higher vocational colleges generally do well in industry-education integration, but the integration level varied greatly from college to college; the performance of some indices should be further optimized.
\end{abstract}

Keywords-Industry-education integration, higher vocational colleges, performance evaluation, Yangtze River Delta

\section{Introduction}

The industry-education integration refers to the optimal configuration and great integration of elements between colleges and industry by fully relying on and utilizing various resources, in order to achieve in-depth cooperation and overall development. Such integration creates opportunities of development for higher vocational colleges. In the long-term operation of schools, higher vocational colleges have begun to focus on the introduction of industry elements in terms of source of students, faculty, and courses, and the integration of industry and education will help them further expand their advantages and improve quality. The development process of industry-education integration is shown as follows: 


\subsection{Preliminary exploration of the industry-education integration reform}

Since the reform and opening-up, especially after the 1990s, China has entered the peak period of economic growth, but there also exist some problems in the industrial technology and international competitiveness, which strongly calls for the combination of industry, university, and research. The experience of many countries also showed that industry university cooperation has become a new trend in the development of international higher education. In the face of the new situation, the concept of China's higher education has gradually changed, and more and more attention has been paid to strengthening the connection with the industry, so as to promote the targeted functions of teaching, scientific research and service of colleges and universities. At the institutional level, a series of documents in the field of education have been promulgated, e.g., the Decision on Education System Reform issued by the Central Committee of the Communist Party of China stated "Strengthening the relationship between higher education institutions and production, scientific research and other aspects of society" [1]; The Outline of China Education Reform and Development promulgated in 1993 also advocates the joint operation of schools based on the integration of industry and education. Meanwhile, in terms of practice, many colleges and enterprises have launched cooperative education. Some colleges regard students' regular internships as one of their courses, and enterprises and institutions provide practice bases and send professionals to guide students; some others provide training for on-duty employees in an organized manner, use their own technological advantages to help the industry solve existing problems, and be entrusted by enterprises to develop high-tech products. Although at this stage, colleges and universities have increasingly attached importance to enterprise, industry and social service issues, and have achieved certain practical experience in cooperation, there are still many problems to be clarified, and the degree of cooperation needs to be further strengthened.

\subsection{The gradual advancement of the industry-education integration reform}

The period from the end of the 1990s to the beginning of the 21 st century was critical for China's modernization, which also proposed higher requirements for the structure and types of higher education. The demand for high-level skilled talents is increasing with the development of economy and society. The combination of production and education has been emphasized in relevant policies. At the same time, more diversified practices have been started. At this stage, the documents such as the Vocational Education Law of the People's Republic of China, Decision on Vigorously Promoting the Reform and Development of Vocational Education, and Decision on Vigorously Developing Vocational Education were issued, which not only refined various national policies and regulations, but also increasingly diversified the reform of different colleges and universities. As early as February, 2007, Zhejiang Technical Institute of Economics and Zhejiang Materials Industry Logistics Investment Co., Ltd. established the first logistics industry college in Zhejiang Province, reflecting the indepth cooperation between the dominant majors of the colleges and leading enterprises in the industry [2]. Based on the regional industrial characteristics and economic 
needs, Zhongshan Polytechnic has explored the development path of professional town and industry colleges following the idea of "one town, one product, and one specialty" [3]. Tianjin Vocational College of Mechanics and Electricity carried out the exploration of the "pre-employment" talent training model, i.e., the employer selects outstanding talents from the sophomore and junior students as the talent reserve and training targets [4]. In this period, many colleges and universities, especially higher vocational colleges, paid more and more attention to cooperation with enterprises, and achieved remarkable results through a series of measures.

\subsection{The deepening of the industry-education integration reform}

In addition to vigorous growth in quantity, the quality and connotation in higher education have also received more attention in recent years. Under the new situation that China's economy has entered the stage of high-quality development and higher education has entered the late stage of popularization, colleges and universities must pay more attention to the problems of characteristics and quality. The number and scale of higher vocational colleges have become stable, it has become an urgent task to improve the quality, and conforming to the trend of industry and education integration has become an important way to use advantages to show characteristics. In December 2017, the General Office of the State Council issued Several Opinions on Deepening the Integration of Industry and Education, stating the necessity and significance of "deepening the integration of industry and education, and promoting the organic connection of the education chain, the talent chain and the industry chain and innovation chain. The policy is elaborated from the aspects of constructing the overall development pattern of industry-education integration, strengthening the important role of enterprises, promoting the talent training reform of industry-education integration, promoting the coordination of industry and education supply and demand, and improving the policy support system. Higher education must greatly contribute to economic development and industrial upgrading. The industry-education integration is a strategic planning for the entire field of education, especially vocational education. It is no longer a simple combination of industry and academia, or loose cooperation between colleges and enterprises, but the in-depth involvement of enterprises and the fundamental changes of colleges on the basis of respecting the laws of education and meeting the industry needs. Therefore, it's necessary for colleges, including higher vocational colleges to focus more on the quality development and performance improvement of the industry-education integration.

\section{Literature Review of Industry-Education Integration}

\subsection{Connotation research on industry-education integration}

The connotation of the industry-education integration is continuously enriched. At first, it's only used as a talent training model. For example, the American Vocational Association defined cooperative education as a combination of theoretical study and 
real work experience. The World Association for Cooperative Education has made further improvements to highlight the compatibility of the two. Later, the integration of industry and education gradually emphasized the cooperative relationship between schools and enterprises. It's believed that this integration is a cooperative activity between higher education and industry to enrich the education process and provide support to the industry. In recent years, it has been increasingly regarded as a systematic institution. Tang et al. [5] took it as a cooperative activity, relationship, and mechanism of resource sharing, complementary advantages, and demand matching. Ma and Guo [6] summarized it as the integration of industry advanced technology, excellent culture and development needs into education teaching resources and processes.

\subsection{Evaluation research on industry-education integration}

Scientific evaluation is required for deepening the integration of industry and education. HellstrÖm and Jacob, [7] proposed that the performance evaluation system of industry-education cooperation should include the indicators such as productivity, financial benefits, education, publications, and patents. Rossi and Rosli [8], based on a survey of 131 British universities, set up a knowledge transfer index system with five dimensions.

Kauppila et al. [9] designed an evaluation framework for cooperation between universities and enterprises based on the EFQM model. Liu et al. [10] discussed the influencing factors of four modes of integrating the industry and education, and established a relation model between the two. Tong and Chen [11] performed a coding analysis for the text using the NVIVO11.0 and built an effect enhancement model of collaborative education.

\subsection{Research on countermeasures for the industry-education integration}

Based on the existing problems, domestic and foreign scholars have proposed corresponding countermeasures. Wright et al. [12] used survey data to analyze the types of cooperation models between colleges and industry based on the technology stage. Xing and $\mathrm{Li}$ [13] made recommendations through a survey of 75 private colleges. Jiang [14] proposed to change the college evaluation standards and mechanisms, improve the results transformation mechanism, and achieve the transformation of scientific research results. Shi and Hao [15] believe that the integration of industry and education should insist on space, time, technology, and system thinking. Zhou and Chen [16] discussed the realization path from the perspective of the synthesis, organism, and symbiosis of the industry-education integration. He [17] emphasized the need to form a four-level integration system of individual, organization, inter-regional organization, and state.

In short, the research on the industry-education integration has become one of the focuses in the academic community in recent years, including performance evaluation. But there is still a lack of in-depth research based on empirical data. 


\section{Index Design for Performance Evaluation of Industry- Education Integration in Higher Vocational Colleges}

In this study, 138 higher vocational colleges were selected from the Yangtze River Delta as the research samples, 2018 data was used for analysis, and the annual report on the quality of higher vocational education, the official website information of the State Intellectual Property Office and each college were taken as data sources. Then, a comprehensive evaluation system was designed (Table 1 and 2).

Table 1. Performance Evaluation Index System of the industry-education Integration in Higher Vocational Colleges

\begin{tabular}{|c|c|c|}
\hline No. & Index & Content \\
\hline $\mathrm{X} 1 \mathrm{I}$ & Ratio of double-qualified teachers & $\begin{array}{l}\text { The percentage of double-qualified teachers to the total number of } \\
\text { full-time teachers }\end{array}$ \\
\hline $\mathrm{X} 2$ & $\begin{array}{l}\text { Annual class hours of part-time } \\
\text { enterprise teachers per student }\end{array}$ & $\begin{array}{l}\text { The total amount of class hours of part-time enterprise teachers } \\
\text { that year, based on the average level of the number of students in } \\
\text { college }\end{array}$ \\
\hline $\mathrm{X} 3 \mid \begin{array}{l}1 \\
1\end{array}$ & $\begin{array}{l}\text { Proportion of graduates staying in } \\
\text { local employment }\end{array}$ & Percentage of local employment in the total number of graduates \\
\hline $\mathrm{X} 4 \mathrm{1}$ & Employer satisfaction of graduates & Percentage of employer satisfaction with graduates \\
\hline $\mathrm{X} 5 \mathrm{~T}_{1}^{\mathrm{T}}$ & $\begin{array}{l}\text { The amount of vertical scientific } \\
\text { research funds received per teacher }\end{array}$ & $\begin{array}{l}\text { Vertical scientific research funds obtained for each full-time } \\
\text { teacher }\end{array}$ \\
\hline X6 & $\begin{array}{l}\text { The amount of technical services } \\
\text { funds received per teacher }\end{array}$ & $\begin{array}{l}\text { The technical contracts signed with natural persons, legal persons } \\
\text { and other organizations, and the funds involved in international } \\
\text { scientific and technological cooperation projects, based on the } \\
\text { average level of the number of full-time teachers }\end{array}$ \\
\hline $\mathrm{X} 7 \mid \begin{array}{l}\mathrm{1} \\
\mathrm{t}\end{array}$ & $\begin{array}{l}\text { Number } \\
\text { teacher }\end{array}$ & $\begin{array}{l}\text { Invention patents that have been authorized and announced based } \\
\text { on the average level of the number of full-time teachers }\end{array}$ \\
\hline$\left.\mathrm{X} 8\right|_{\mathrm{t}} ^{\mathrm{t}}$ & $\begin{array}{l}\text { Economic benefits generated by } \\
\text { technical services per teacher }\end{array}$ & $\begin{array}{l}\text { Relevant services for natural persons, legal persons and other } \\
\text { organizations, and the economic benefits generated in internation- } \\
\text { al scientific and technological cooperation projects, based on the } \\
\text { average level of the number of full-time teachers }\end{array}$ \\
\hline $\mathrm{X} 9 \mathrm{t}_{\mathrm{t}}$ & $\begin{array}{l}\text { The amount of non-academic } \\
\text { training per teacher }\end{array}$ & $\begin{array}{l}\text { The received funds for non-academic training for the society, } \\
\text { based on the average level of the number of full-time teachers }\end{array}$ \\
\hline $\mathrm{X} 10$ & $\begin{array}{l}\text { Daily public welfare training } \\
\text { service per teacher }\end{array}$ & $\begin{array}{l}\text { The scale of free training provided to the society according to the } \\
\text { average number of full-time teachers }\end{array}$ \\
\hline $\mathrm{X} 1$ & $\begin{array}{l}\text { The amount of technical transac- } \\
\text { tions funds received per teacher }\end{array}$ & $\begin{array}{l}\text { The government or enterprise purchases patents and technologies } \\
\text { of universities through the technology market to the account, and } \\
\text { the average level is calculated based on the number of full-time } \\
\text { teachers }\end{array}$ \\
\hline
\end{tabular}


Table 2. Basic information of the samples

\begin{tabular}{|c|c|c|c|}
\hline \multicolumn{2}{|r|}{ Basic information } & Quantity & Percentage $(\%)$ \\
\hline \multirow{4}{*}{ Region } & Shanghai & 19 & $13.77 \%$ \\
\hline & Zhejiang Province & 32 & $23.19 \%$ \\
\hline & Jiangsu Province & 52 & $37.68 \%$ \\
\hline & Anhui Province & 35 & $25.36 \%$ \\
\hline \multirow{4}{*}{ Scale } & Below 5,000 & 37 & $26.81 \%$ \\
\hline & $5,001-10,000$ & 73 & $52.90 \%$ \\
\hline & $10,001-15,000$ & 25 & $18.12 \%$ \\
\hline & Above 15,000 & 3 & $2.17 \%$ \\
\hline \multirow{9}{*}{ Category } & Engineering & 55 & $39.86 \%$ \\
\hline & Comprehensive & 43 & $31.17 \%$ \\
\hline & Finance & 18 & $13.04 \%$ \\
\hline & Medicine & 11 & $7.97 \%$ \\
\hline & Teachers & 3 & $2.17 \%$ \\
\hline & Agriculture and Forestry & 3 & $2.17 \%$ \\
\hline & Art & 2 & $1.45 \%$ \\
\hline & Sports & 2 & $1.45 \%$ \\
\hline & Language & 1 & $0.72 \%$ \\
\hline
\end{tabular}

\section{Data Analysis for Performance Evaluation of Industry- Education Integration in Higher Vocational Colleges}

\subsection{Analysis for mean and standard deviation}

The mean and standard deviation can reflect the overall level of the samples and the degree of differences within the groups to a certain extent. Table 3 below lists the mean and standard deviation of the overall sample and the 11 indices in four regions.

Table 3. Means and standard deviations of 11 indices

\begin{tabular}{|c|c|c|c|c|c|}
\hline Index & $\begin{array}{c}\text { Mean of overall } \\
\text { sample }\end{array}$ & $\begin{array}{c}\text { Standard } \\
\text { deviation of } \\
\text { overall sample }\end{array}$ & $\begin{array}{c}\text { Mean of } \\
\text { Shanghai } \\
\text { samples }\end{array}$ & $\begin{array}{c}\text { Standard deviation } \\
\text { of Shanghai } \\
\text { samples }\end{array}$ & $\begin{array}{c}\text { Mean of } \\
\text { Zhejiang } \\
\text { samples }\end{array}$ \\
\hline X1 & 0.71 & 0.19 & 0.61 & 0.17 & 0.85 \\
\hline X2 & 9.44 & 6.92 & 5.81 & 4.64 & 10.21 \\
\hline X3 & 0.57 & 0.23 & 0.70 & 0.12 & 0.53 \\
\hline X4 & 2.39 & 0.49 & 2.38 & 0.51 & 2.13 \\
\hline X5 & 0.81 & 1.28 & 1.19 & 1.46 & 1.01 \\
\hline X6 & 7.39 & 66.41 & 41.32 & 179.12 & 1.99 \\
\hline X7 & 0.15 & 0.22 & 0.01 & 0.03 & 0.19 \\
\hline X8 & 7.53 & 22.43 & 0.18 & 0.64 & 15.92 \\
\hline X9 & 1.89 & 2.41 & 2.16 & 2.98 & 2.91 \\
\hline X10 & 117.56 & 254.03 & 24.19 & 44.75 & 171.32 \\
\hline X11 & 0.73 & 1.47 & 0.01 & 0.04 & 0.97 \\
\hline Index & $\begin{array}{c}\text { Standard devia- } \\
\text { tion of Zhejiang }\end{array}$ & $\begin{array}{c}\text { Mean of } \\
\text { Jiangsu samples }\end{array}$ & $\begin{array}{c}\text { Standard } \\
\text { deviation of }\end{array}$ & $\begin{array}{c}\text { Mean of Anhui } \\
\text { samples }\end{array}$ & $\begin{array}{c}\text { Standard } \\
\text { deviation of }\end{array}$ \\
\hline
\end{tabular}


Paper-Performance Evaluation of Industry-Education Integration in Higher Vocational Colleges...

\begin{tabular}{|c|c|c|c|c|c|}
\hline & samples & & Jiangsu samples & & Anhui samples \\
\hline X1 & 0.06 & 0.81 & 0.11 & 0.51 & 0.19 \\
\hline X2 & 3.89 & 13.69 & 7.95 & 4.43 & 3.34 \\
\hline X3 & 0.24 & 0.62 & 0.23 & 0.45 & 0.23 \\
\hline X4 & 0.57 & 2.44 & 0.46 & 2.55 & 0.35 \\
\hline X5 & 1.38 & 0.77 & 1.14 & 0.49 & 1.25 \\
\hline X6 & 2.14 & 3.13 & 4.42 & 0.21 & 0.87 \\
\hline X7 & 0.19 & 0.27 & 0.26 & 0.01 & 0.02 \\
\hline X8 & 34.78 & 9.99 & 22.53 & 0.18 & 0.65 \\
\hline X9 & 2.34 & 1.61 & 1.49 & 1.26 & 2.97 \\
\hline X10 & 183.25 & 93.82 & 138.87 & 154.36 & 435.39 \\
\hline X11 & 1.54 & 1.32 & 1.86 & 0.02 & 0.06 \\
\hline
\end{tabular}

The performance of higher vocational colleges in different regions varies in terms of 11 indices. From the above table, it can be found that 3 indices of the Shanghai sample, 8 of the Zhejiang sample, 7 of the Jiangsu sample, and 2 of the Anhui sample were higher than the mean value. Specifically, the ratio of double-qualified teachers in Zhejiang and Jiangsu reached more than $80 \%$; the amount of annual class hours of part-time enterprise teachers per student in Jiangsu ranked first, followed by Zhejiang; the percentage of graduates staying in the local employment in Shanghai was the highest; Anhui had the best performance in employer satisfaction with graduates; the vertical research funding per teacher was higher than the mean both in Shanghai and Zhejiang; Shanghai far exceeded the other three regions for the amount of technical services funds received per teacher; Anhui had the most invention patents per teacher, Zhejiang Second; Zhejiang and Jiangsu ranked first and second in the economic benefits of technical services per teacher; Zhejiang and Shanghai were higher in the amount of non-academic training for teachers; Zhejiang and Anhui performed better for public welfare training services per teacher; the amount of technical transactions funds received in Jiangsu and Zhejiang was higher than the mean.

Through analysis for the standard deviations of 11 indices, it can be found that the ratio of double-qualified full-time teachers, the proportion of graduates staying in local employment, and the number of invention patents per teacher had the smallest standard deviations, indicating that the higher vocational colleges in the Yangtze River Delta have made great progress in hiring teachers with practical abilities and industry experience, and the gap between them is small. The Yangtze River Delta region is generally more developed, so it's an ideal place to work, and the proportion of graduates employed locally is generally higher, close to or up to $50 \%$. Higher vocational colleges in the four regions scored less in the invention patent acquisition, which needs further improvement. The standard deviation of the three indices such as the daily public welfare training service per teacher, the amount of technical services funds per teacher, and the economic benefits generated by the technical services per teacher were the maximum; the daily public welfare training service differs due to the importance of each college, and the latter two indices are both related to technical services, indicating that these colleges are different distinctly in their strength of undertaking socially entrusted projects. 


\subsection{Correlation analysis}

Correlation analysis can describe the degree of closeness between things, expressed by the correlation coefficients. As the absolute value of the correlation coefficient is closer to 1 , the correlation between the two variables becomes greater. Table 4 below shows the correlation analysis of 11 indices.

From Table 4 above, it can be seen that there are high correlations between variables, i.e., between the ratio of double-qualified teachers and the indices representing the scientific research ability in higher vocational colleges such as the amount of vertical scientific research funding per teacher, the amount of technical service funds per teacher, the number of invention patents per teacher, and the economic benefits generated by the technical service per teacher; between the ratio of double-qualified teachers and the indices meeting the market demands such as the amount of nonacademic training, the daily public welfare training service per teacher, and the amount of technical transactions funds received; between the ratio of double-qualified teachers and the indicators such as the annual class hours of part-time enterprise teachers per student and the proportion of graduates staying in the local employment; between the employer satisfaction of graduate and the proportion of graduates staying in local employment. The above indices are all significantly correlated at the $1 \%$ level.

Table 4. Correlation coefficients of 11 indices

\begin{tabular}{|c|c|c|c|c|c|c|c|c|c|c|c|}
\hline & $\mathbf{X 1}$ & $\mathbf{X 2}$ & $\mathbf{X 3}$ & $\mathbf{X 4}$ & $\mathbf{X 5}$ & $\mathbf{X 6}$ & $\mathbf{X 7}$ & $\mathbf{X 8}$ & $\mathbf{X 9}$ & $\mathbf{X 1 0}$ & $\mathbf{X 1 1}$ \\
\hline $\mathrm{X} 1$ & 1 & 0.52 & 0.27 & -0.09 & 0.29 & 0.38 & 0.69 & 0.55 & 0.41 & 0.47 & 0.55 \\
\hline $\mathrm{X} 2$ & 0.52 & 1 & 0.27 & -0.00 & 0.12 & 0.25 & 0.60 & 0.46 & 0.23 & 0.36 & 0.42 \\
\hline $\mathrm{X} 3$ & 0.27 & 0.27 & 1 & 0.23 & 0.21 & 0.32 & 0.22 & 0.25 & 0.16 & 0.14 & 0.34 \\
\hline $\mathrm{X} 4$ & -0.09 & -0.00 & 0.23 & 1 & 0.08 & 0.15 & -0.06 & 0.08 & -0.07 & 0.12 & 0.21 \\
\hline $\mathrm{X} 5$ & 0.29 & 0.12 & 0.21 & 0.08 & 1 & 0.39 & 0.25 & 0.39 & 0.34 & 0.23 & 0.41 \\
\hline $\mathrm{X} 6$ & 0.38 & 0.25 & 0.32 & 0.15 & 0.39 & 1 & 0.45 & 0.49 & 0.24 & 0.37 & 0.47 \\
\hline $\mathrm{X} 7$ & 0.69 & 0.60 & 0.22 & -0.06 & 0.25 & 0.45 & 1 & 0.67 & 0.32 & 0.44 & 0.61 \\
\hline $\mathrm{X} 8$ & 0.55 & 0.26 & 0.25 & 0.08 & 0.39 & 0.49 & 0.67 & 1 & 0.38 & 0.39 & 0.65 \\
\hline $\mathrm{X} 9$ & 0.41 & 0.23 & 0.16 & -0.07 & 0.34 & 0.24 & 0.32 & 0.38 & 1 & 0.42 & 0.33 \\
\hline $\mathrm{X} 10$ & 0.47 & 0.36 & 0.14 & 0.12 & 0.23 & 0.37 & 0.44 & 0.39 & 0.42 & 1 & 0.43 \\
\hline $\mathrm{X} 11$ & 0.55 & 0.42 & 0.34 & 0.21 & 0.41 & 0.47 & 0.61 & 0.65 & 0.33 & 0.43 & 1 \\
\hline
\end{tabular}

\subsection{Factor analysis}

According to the data structure and evaluation objectives, factor analysis is a more appropriate evaluation method. Table 5 below reflects the factor analysis results of 11 indices. The results show that the rotated 3 -factor model is sufficient to explain the differences contained in this data. 
Table 5. Factor analysis of 11 indices

\begin{tabular}{|c|c|c|c|}
\hline & Factor 1 & Factor 2 & Factor 3 \\
\hline $\mathrm{X} 1$ & 0.700 & 0.347 & 0.066 \\
\hline $\mathrm{X} 2$ & 0.647 & 0.112 & 0.046 \\
\hline $\mathrm{X} 3$ & 0.208 & 0.130 & 0.380 \\
\hline $\mathrm{X} 4$ & 0.094 & -0.075 & 0.519 \\
\hline $\mathrm{X} 5$ & 0.185 & 0.379 & 0.396 \\
\hline $\mathrm{X} 6$ & 0.409 & 0.212 & 0.435 \\
\hline $\mathrm{X} 7$ & 0.903 & 0.162 & 0.074 \\
\hline $\mathrm{X} 8$ & 0.648 & 0.294 & 0.348 \\
\hline $\mathrm{X} 9$ & 0.206 & 0.801 & 0.011 \\
\hline $\mathrm{X} 10$ & 0.407 & 0.402 & 0.172 \\
\hline X11 & 0.588 & 0.253 & 0.504 \\
\hline SS loadings & 2.951 & 1.323 & 1.177 \\
\hline Proportion Var & 0.268 & 0.120 & 0.107 \\
\hline Cumulative Var & 0.268 & 0.389 & 0.496 \\
\hline
\end{tabular}

In Table 5 above, all load factors form a load matrix, which represents the correlation between a factor and each index. The larger number of load factor indicates a greater correlation. Factor 1 is highly correlated with those indices other than the proportion of graduates staying in the local employment, the employer satisfaction of graduates, the amount of vertical research funding per teacher, and the amount of nonacademic training per teacher. Factor 2 is highly correlated to the amount of vertical scientific research funds received per teacher, the amount for non-academic training per teacher, and daily public welfare training service per teacher. Factor 3 is highly correlated to the proportion of graduates staying in the local employment, the employer satisfaction of graduates, the amount of vertical research funding per teacher, the amount of technical service funds per teacher, and the amount of technology transaction funds per teacher.

The SS loadings and Proportion Variance of the three factors indicate the degree of the factor's role in explaining the difference in the overall data, and then calculate the weight of the three factors. Taking Factor 1 as an example, its weight was 2.951 / $(2.951+1.323+1.177)$, and thus the weights of the three factors were $0.541,0.243$, and 0.216 . Then, according to the scores and weights of the three factors, a weighted average score was calculated, to rank the performance of 138 higher vocational colleges for the integration of industry and education. The results showed that among the top 10 well-performed universities, 6 were in Jiangsu, and 4 were from Zhejiang; although some colleges of Shanghai and Anhui were in the top 60, they still fell behind in the total numbers of top colleges compared with Jiangsu and Zhejiang. This may be related to the total number of samples in different regions, e.g., Shanghai had only 19 samples. But Jiangsu and Zhejiang still had obvious advantages, i.e., the samples of Jiangsu accounted for $61.67 \%$ of the top 60 colleges, which was significantly higher than the $37.68 \%$ of the 138 samples, indicating that the integration of industry and education in higher vocational colleges does have a stronger comprehensive strength among the four regions. 


\section{Conclusion}

First, the industry-education integration of higher vocational colleges in the Yangtze River Delta region generally is good in performance based on the 11 indices. For example, the average ratio of double-qualified teachers was as high as $71 \%$, and the highest was $94 \%$; the average proportion of graduates staying in the local employment was $57 \%$, and the highest was $95 \%$; 30 vocational colleges received annual technical services funds for the total amount of more than 10 million yuan, and 25 colleges received total annual vertical scientific research funding of more than 5 million yuan; 29 had the total annual non-academic training funds for more than 10 million yuan. This indicates that higher vocational colleges have fully realized the importance of grasping needs, integrating into the industry, and serving the society, and achieved certain results, e.g., they have hired more people familiar with first-line production management practices as teachers to engage in teaching and scientific research; graduate students initially possess the ability to work in the region and win a certain degree of regional recognition; in addition to teaching, they have also begun to accelerate the pace of industry-education integration by undertaking various projects at all levels, while gradually focusing on serving the society to enhance their influence.

Second, the performance development of the industry-education integration in higher vocational colleges of the Yangtze River Delta region is unbalanced. The comparison of the four regions in the Yangtze River Delta shows that in addition to the limited number of samples, the imbalance in the performance development of the industry-education integration in higher vocational colleges is still quite obvious. Generally, higher vocational colleges in Jiangsu and Zhejiang are relatively stronger in the field of industry-education integration, while Shanghai and Anhui still have more room for improvement in this regard. The imbalance is not only reflected between provinces but also within provinces and cities. For example, among the top 30 vocational colleges in Jiangsu, there were 7 in Nanjing, 7 in Changzhou, 5 in Nantong, 4 in Suzhou, 3 in Wuxi, 3 in Zhenjiang, and 2 in Taizhou; among the top 20 vocational colleges in Zhejiang, there were 8 in Hangzhou, 3 in Wenzhou, and 3 in Ningbo; among the top 20 vocational colleges in Anhui province, there were 6 in Hefei, 3 in Huainan, and 2 in Wuhu, and 2 in Tongling. Most of them are relatively developed in the economic levels. The imbalance in the performance level of the industry-education integration in higher vocational colleges is not only related to their own development history, professional characteristics, and college strength, but also deeply affected by the local economic environment, college layout and regional policies.

Thirdly, the performance of some indices in the industry-education integration in higher vocational colleges needs to be optimized. Despite of the good performance of higher vocational colleges, there are still many indices unsatisfactory, especially in providing scientific and technological services and meeting market needs. Although the total funding for vertical scientific research projects in some higher vocational colleges has reached a considerable scale, it is not satisfactory if calculated per teacher. Only 34 vocational colleges have received more than 10,000 yuan of vertical scientific research funds, 51 received more than 10,000 yuan of technical services funds, 
and 30 received more than 10,000 technical transactions funds. In addition to funding, the number of invention patents per teacher and the economic benefits of technical services per teacher are also rare; the former was 0 in the 40 higher vocational colleges; the latter in 87 higher vocational colleges was below 10,000 yuan. Thus, the integration of industry and education in higher vocational colleges has been involved in various fields, but it is still insufficient in depth and effectiveness. More efforts are needed to contribute to society and create benefits.

Also, higher vocational colleges in the Yangtze River Delta region need to further explore their own characteristics, make full use of regional advantages, strengthen cross-regional cooperation, optimize relationships with enterprises, grasp policy guidance, and respect market rules, for achieving continuous advancement, gradual deepening, and sustainable development.

\section{Acknowledgement}

This paper is supported by 2020 Planning Program of Philosophy and Social Sciences in Zhejiang Province "Research on the Evaluation Model and Promotion Path of University Industry-Education Integration Performance from the Perspective of Resource Integration-Taking Zhejiang Province as an Example" (No. 20NDJC166 YB).

\section{$7 \quad$ References}

[1] Central Committee of the Communist Party of China. Decision on Education System Reform [EB/OL]. http://www.moe.gov.cn/jyb sjzl/moe 177/tnull 2482.html.1985.05.27

[2] Zhejiang Technical Institute of Economics. Constructing the University Enterprise Partnership and Exploring the New Mode of Higher Vocational Education in China. Zhejiang Daily.2007-06-13.

[3] Zhongshan Polytechnic. Integration into Regional Economy, Unlimited Vitality of Vocational Education. Zhongguo Jiaoyu Bao, 2011-09-24.

[4] Zhao, Y.X., Shi, H.Y., Wei, Y.J. (2007). Study on Cultivating Pattern of "Combining Learning with Working" in Higher Vocational Education. Journal of Tianjin Vocational Institutes, 9(1): 42-45.

[5] Tang, W.B., Wen, H. Peng, J.P. (2018). Construction of Collaborative Education Mechanism under the Concept of "Integration of Industry and Education". China Higher Education, (8): 14-16.

[6] Ma, S.C., Guo, W.F. (2018). Experiences, problems and countermeasures in deepening industry-university integration of technical and vocational higher education. China Higher Education Research, (4): 58-61.

[7] HellstrÖm, T., Jacob, M. (1999). Evaluating and managing the performance of universityindustry partnerships: From central rule to dynamic research networks. Evaluation, 5(3): 330-339.https://doi.org/10.1177/13563899922209011

[8] Rossi, F., Rosli, A. (2015). Indicators of University-industry Knowledge Transfer Performance and Their Implications for Universities: Evidence from the United Kingdom. 
Studies in Higher Education, 40(10): 1970-1991. https://doi.org/10.1080/03075079.2014. $\underline{914914}$

[9] Kauppila, O., Mursula, A., Harkonen, J., Kujala, J. (2015). Evaluating University-industry Collaboration: the European Foundation of Quality Management Excellence Model-based Evaluation of University-industry Collaboration. Tertiary Education and Management, 21(3): 229-244. https://doi.org/10.1080/13583883.2015.1045550

[10] Liu, Y.R., Xiang, G.E., Wang, J.C. (2015). Research on the Model of the Fusion of Education and Industry in Application-oriented Universities and its Influencing Factors. China Higher Education Research, (5): 64-68.

[11] Tong, L., Chen Z.J. (2019). How can the Integration of Industry and Education be Effective? -Analysis based on organizational commitment framework. Chinese Vocational and Technical Education, (6): 58-65.

[12] Wright, M., Clarysse, B., Lockett, A., Knockaert, M. (2008). Mid-range Universities' Linkages with Industry: Knowledge Types and the Role of Intermediaries. Research Policy, 37(8): 1205-1223.https://doi.org/10.1016/j.respol.2008.04.021

[13] Xing, H., Li, Y.Z. (2015). Investigation and analysis on the current situation of industry education integration in private colleges and universities. Education and Vocation, (36): 24-27.

[14] Jiang, D.Y. (2018). Colleges and universities should enhance the ability to deeply participate in the integration of industry and education. China Higher Education, (2): 2324.

[15] Shi, W.P., Hao, T.C. (2019). From school-enterprise cooperation to industry-education integration: The redirection of vocational education running mode reform in China. Research in Educational Development, (1): 1-9.

[16] Zhou, J.S., Chen, Z.J. (2019). Realization path of industry education integration in higher vocational colleges based on college development system. Education and Vocation, (5): 31-35.

[17] He, Z. (2014). Establishing modern vocational education governance system and promoting system innovation of industry education integration. Chinese Vocational and Technical Education, (21): 138-142.

\section{Authors}

Fei Gao, as the associate researcher of Non-governmental Higher Education Institute of China, Zhejiang Shuren University, has been committed to the research in the field of higher education evaluation for a long time. She has published several core papers and finished several important projects. Email: gaofeibd@163.com

Peng Zhang, as the professor of School of Mathematical Sciences, Zhejiang University, has published many core papers and finished many important projects. Email: pengz@zju.edu.cn

Article submitted 2020-10-10. Resubmitted 2020-11-16. Final acceptance 2020-11-18. Final version published as submitted by the authors. 